ISSN 0103-5150

Fisioter. Mov., Curitiba, v. 30, n. 3, p. 625-637, Jul./Sep. 2017

Licenciado sob uma Licença Creative Commons

DOI: http://dx.doi.org/10.1590/1980-5918.030.003.AR03

(c) (i)

\title{
Assessment instruments of functioning in Brazilian elderly and the ICF: a systematic review
}

\author{
Instrumentos de avaliação da funcionalidade em idosos \\ brasileiros e a CIF: uma revisão sistemática da literatura
}

\author{
Cíntia Sulino Gomes $^{[a]}$, Mariana Colombini Buranello ${ }^{[a]}$, Shamyr Sulyvan Castro ${ }^{[b] *}$
}

[a] Universidade Federal do Triângulo Mineiro (UFTM), Uberaba, MG, Brazil

[b] Universidade Federal do Ceará (UFC), Fortaleza,CE, Brazil

\section{Abstract}

Introduction: Under the new conceptual model described by the International Classification of Functioning Disability and Health (ICF) for a biopsychosocial health analysis, it is necessary to consider that it is not arising only from biological conditions, but also environmental, social, cultural and politics involved in this process. Objective: To review the publications that had the Brazilians elderly functioning as outcome by analyzing the instruments used and to verify its consistency with the ICF model. Methods: A systematic review of the Brazilian literature on elderly was performed in SciELO, PubMed, Scopus, and Lilacs databases. Publications starting in 2001, in English, Portuguese or Spanish, studies with experimental design or intervention, having the Brazilian elderly as the only subject. For evaluating the quality of the papers, the Downs and Black checklist were used. Results: From 3070 items first found in the research, 29 articles remained for this study. Of these, 25 instruments were used to measure the eldery functioning. The frequency of the ICF domains were: health condition (0.28\%), body structure and function (1.71\%), activity (82.34\%), participation (3.42\%), environmental factors (12.25\%) and personal factors $(0 \%)$. Conclusion: Despite the ICF be much discussed today, it was possible to detect remaining gaps in the studies about the subject. The

CSG: undergrad, e-mail: cintia.gomes6@etec.sp.gov.br

MCB: MS, e-mail: colombiniburanello@gmail.com

SSC: PhD, e-mail: shamyrsulyvan@gmail.com 
results of this study indicate that the conceptual model has not being fully and equitably used when it comes to the eldery functioning.

Keywords: Aged. International Classification of Functioning, Disability and Health. Review.

\section{Resumo}

Introdução: Sob o novo modelo conceitual descrito pela Classificação Internacional de Funcionalidade Incapacidade e Saúde (CIF), para uma análise biopsicossocial da saúde, torna-se necessário considerar que ela não é advinda apenas das condições biológicas, mas também de fatores ambientais, sociais, culturais e políticos envolvidos neste processo. Objetivo: Revisar as publicações que possuem como desfecho a funcionalidade de idosos brasileiros analisando os instrumentos utilizados para sua avaliação e verificar sua coerência com o modelo da CIF. Métodos: Foi realizada uma pesquisa de revisão sistemática da literatura, nas bases de dados SciELO, PubMed, Scopus e Lilacs. Foram incluídas publicações a partir de 2001, nos idiomas inglês, português ou espanhol, estudos com desenho experimental ou de intervenção, tendo como sujeitos de estudo apenas idosos brasileiros. Para a avaliação da qualidade dos artigos incluídos, foi utilizado o Checklist de Downs e Black. Resultados: Dos 3070 artigos encontrados, após leitura minuciosa, restaram 29. Destes, foram selecionados 25 instrumentos que foram utilizados para medir a funcionalidade do idoso, onde a frequência dos domínios da CIF foi: condição de saúde (0,28\%), função e estrutura do corpo (1,71\%), atividade (82,34\%), participação (3,42\%), fatores ambientais (12,25\%) e fatores pessoais (0\%). Conclusão: Apesar da CIF ser muito discutida na atualidade, foi possível detectar lacunas ainda existentes nos estudos acerca do tema. Os resultados da presente pesquisa apontam que o modelo conceitual não está sendo utilizado em sua totalidade e de forma equânime quando se trata de funcionalidade em idosos.

Palavras-chave: Idoso. Classificação Internacional de Funcionalidade, Incapacidade e Saúde. Revisão.

\section{Introduction}

From the 70s, the demographic transition in Brazil marks an accelerated process of population aging, arising from advances and discoveries in health care, and better living conditions of the population that has the effect of a change in morbidity and mortality patterns. The prevalence of diseases that were transmittable (infectious) changes to the prevalence of chronic degenerative diseases and external causes (1).

The reflection of this growth in the number of elderly in Brazil is increasingly significant over the years. Added to the fact that with advancing age occur morphological, functional and biochemical changes that cover the entire body and determine the progressive loss of the individual's ability to adapt to the environment, causing greater vulnerability (2). The aging produces a reduced functional capacity of the person, making this person dependent on some activities performed on a day-to-day, requiring a correct evaluation of its functioning to identify the main deficiencies and difficulties (3).

In this context, the International Classification of Functioning, Disability and Health (ICF), proposed by the World Health Organization (WHO), addresses the functioning and disability with a biopsychosocial context, analyzing the interaction of the various factors involved in health, be them biological, social or personal, considering the environmental and individual conditions in this interaction (4).

This way, ICF brings a new challenge to the concept and analysis of health, focused on incapacity and disability, as it believes that they are not only from the biological conditions of the disease, but also from the environmental, social, cultural and political facts involved in this case (5).

According to the WHO (4), you can see on the IFC a conceptual diagram, where there are six areas that allow a multidimensional relationship of the functioning to be made. The domains of the ICF are the functions and body structures, activity, participation 
and environmental factors. The relationship between the components of the IFC is dynamic; in other words, the functioning of an individual is the result of an interaction or complex relationship between these elements, the body functions and body structures, activities, participation and contextual factors (environmental and personal factor). The ICF allows to describe the functioning of the human being and serves as a standard language, allowing the standardized sharing of such information to various places and people (4).

This systematic literature review aims to collect and study instruments used for measuring the elderly functioning as an endpoint in Brazilian scientific articles and verify its consistency with the IFC model. The aim is to thus detect whether the design of the elderly functioning in Brazilian research reveals some relationship with the IFC. Also, this review will guide the choice of instruments for use in measuring the functioning in the clinical and research environment.

\section{Methods}

This study is a systematic review of the literature searched between September 2015 and February 2016, using the bases Scientific Electronic Library Online (SciELO), PubMed, Scopus, and Lilacs in English, Portuguese and Spanish.

For bibliographic search descriptors were established: Elderly; Very old; Evaluation; Frail elderly and their counterparts in English and Spanish. And the key words: Disability; Functional performance; Functioning; Functional capacity; Disabilities and their counterparts in English and Spanish. The combination of descriptors were: [C"Inability" OR "Functional Performance" OR "Functioning" OR "Functional Capacity" OR "Deficiency") AND ("Senior" OR "Very Elderly" OR "Frail Elderly")].

The selection of articles followed the following inclusion criteria: articles written from 2001 (ICF publication date), studies with experimental design or only Brazilian elderly population in the study and intervention. And the exclusion criteria were: review articles, observational studies, cross-sectional studies and those that did not address the functioning as the outcome variable or study.

Initially, research and inclusion of articles was carried out by two researchers independently. In a second moment the results were compared and in case of divergences between any articles, with the support of a third experienced researcher in the subject, was decided on the inclusion of the article.

The articles were evaluated by the title and the summary as to its eligibility according to the inclusion and exclusion criteria. After this step, the articles were read in full and could still be excluded if they do not fulfill the eligibility criteria. The following data were extracted from studies found: author/year of publication; composition of the sample; scale assessment of functioning; outcome studied.

The studies that met the inclusion criteria were evaluated according to the methodological quality checklist described by DOWNS and BLACK (6), composed of 27 questions divided into five sections: Study Quality (10 items), general quality of the study; External validity (3 items), ability to generalize findings of the study; Internal validity (7 items), evaluate the bias in the intervention and outcome; Confounding bias and selection (6 items), determine the bias from the sampling or group work; Study power. In this review an adaptation was performed where only 26 items were used to evaluate the methodological quality of the article and have not used any cut-off point for selection. As already done by other authors, item 27 of the questionnaire corresponding to "power" session was not used $(7,8)$.

The second stage of the research consisted of the codification of the instruments used in research in the evaluation process of the elderly functioning for ICF domains. The encoding process consists of the extraction of significant concepts of the outcomes of the articles. These outcomes could be scales, questionnaires, questions or any other strategy used in the articles to assess functioning. Once extracted, these concepts were codified for the domains of ICF by two independent coders in accordance with established and published rules (9). Finally, the products of the two codings were compared and discrepancies resolved with the supervision of a third investigator encoder.

For the database storage, reading and selection of articles, was used StArt 2.3.4.2 program (State of the Art through Systematic Review), developed by the Research in Sofware Laboratory of the Federal University of São Carlos (LaPES - Ufscar). This tool is used to look for evidence in the scientific literature, conducted in a formal manner, using well-defined stages, according to a well-designed protocol (10). In the second stage of the Project, for processing, data analysis and creating charts, Excel $^{\circledR} 2011$ program was used. 


\section{Results}

Initially, the first search resulted in 3070 articles.

exclusion of articles, were considered for review 29 publications. Figure 1 demonstrates a flow chart with After the accomplishment of all steps of inclusion and

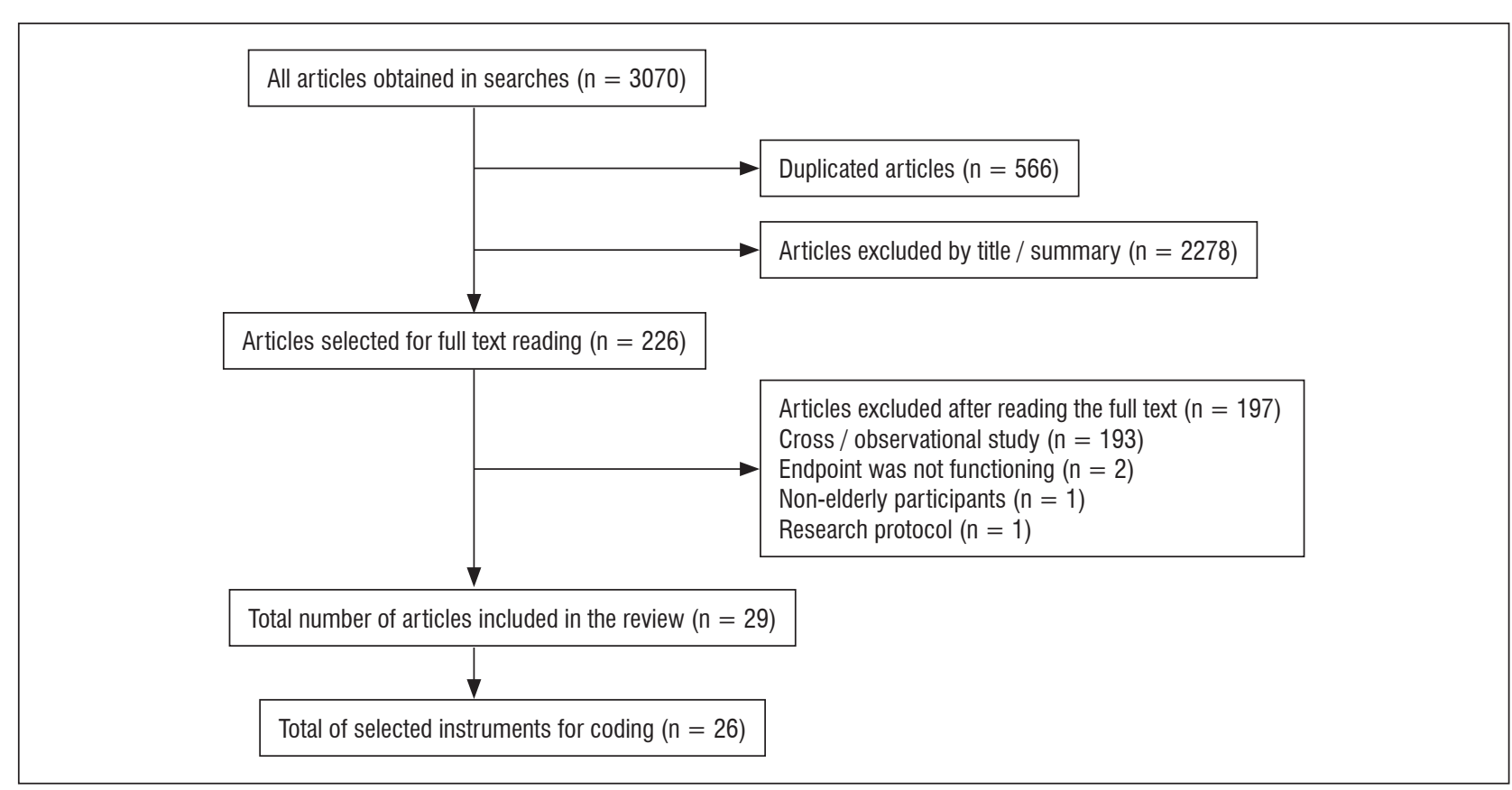

Figure 1 - Selection flowchart of review articles.

Regarding the articles included in the review, according to Downs and Black Checklist, which evaluated the methodological quality of these, the minimum obtained score was 10 and the maximum 22, with an average of 16.9 for 27 questions. In Table 1 we have the overview of the articles included in the review.

Table 1 - General distribution of the studied articles according to the sample characteristics, aims, functional measurement instrument used and quality score

\begin{tabular}{|c|c|c|c|c|}
\hline Author / Year & $\begin{array}{c}\text { Total sample } \\
\text { number * }\end{array}$ & Aim & $\begin{array}{l}\text { Instrument } \\
\text { Functioning }\end{array}$ & $\begin{array}{l}\text { Quality } \\
\text { Score ** }\end{array}$ \\
\hline $\begin{array}{l}\text { Bastone e Jacob } 2004 \\
\text { (11) }\end{array}$ & 37 & $\begin{array}{l}\text { To determine the effectiveness of a } 6 \\
\text { months exercise program for functional } \\
\text { performance of institutionalized elderly. }\end{array}$ & $\begin{array}{l}\text { Obstacle course test (OCQTS e } \\
\text { OCQLS); Lower-limb function } \\
\text { test; } 6 \text { min. walking test. }\end{array}$ & 20 \\
\hline $\begin{array}{l}\text { Montenegro e Silva } \\
2007 \text { (12) }\end{array}$ & 42 & $\begin{array}{l}\text { To analyze the effects of a health promoter } \\
\text { program on functional capacity and their } \\
\text { sociodemographic and clinical variables in } \\
\text { institutionalized elderly. }\end{array}$ & $\begin{array}{l}\text { HAQ (Health Assessment } \\
\text { Questionnaire). }\end{array}$ & 13 \\
\hline $\begin{array}{l}\text { Bottaro, Machado, } \\
\text { Nogueir, Scales, Veloso. } \\
2007 \text { (13) }\end{array}$ & 24 & $\begin{array}{l}\text { To investigate the } 10 \text { weeks effect of } \\
\text { intense verses traditional training program. }\end{array}$ & $\begin{array}{l}\text { Arm Curl Test; sitting down and } \\
\text { standing up from the chair test. } \\
\text { (30 sec); } 8 \text { Foot Up And Go. }\end{array}$ & 16 \\
\hline $\begin{array}{l}\text { Barbosa, Prates, } \\
\text { Gonçalves, Aquino, } \\
\text { Parentoni. } 2008 \text { (14) }\end{array}$ & 35 & $\begin{array}{l}\text { To evaluate the effect of } 6 \text { different dual } \\
\text { tasks in the comunity elderly functional } \\
\text { performance. }\end{array}$ & Timed up and go test. (TUG). & 19 \\
\hline $\begin{array}{l}\text { Geraldes, Carvalho, } \\
\text { Junior, Farinatti, } \\
\text { Albuquerque } 2007 \text { (15) }\end{array}$ & 24 & $\begin{array}{l}\text { To observe the effects of } 12 \text { weeks of } \\
\text { resistance training, on muscle and power } \\
\text { strenght and functional performance. }\end{array}$ & $\begin{array}{l}10 \mathrm{~m} \text { walking test; up from the } \\
\text { kneeling position (UKP); Sit } \\
\text { down and stand up form the } \\
\text { chair } 5 \text { times. }\end{array}$ & 19 \\
\hline
\end{tabular}




\begin{tabular}{|c|c|c|c|c|}
\hline Author / Year & $\begin{array}{c}\text { Total sample } \\
\text { number * }\end{array}$ & Aim & $\begin{array}{l}\text { Instrument } \\
\text { Functioning }\end{array}$ & $\begin{array}{l}\text { Quality } \\
\text { Score ** }\end{array}$ \\
\hline $\begin{array}{l}\text { Carvalho e Assini } 2008 \\
\text { (16) }\end{array}$ & 39 & $\begin{array}{l}\text { To check the improvement of functional } \\
\text { capacity among elderly people undergoing } \\
\text { an intervention by isostretching. }\end{array}$ & 6 min walking test (6WT). & 15 \\
\hline $\begin{array}{l}\text { Perez, Zimperer, Silva. } \\
2009 \text { (17) }\end{array}$ & 29 & $\begin{array}{l}\text { To evaluate the effects of a program of } \\
\text { aquatic exercise in ADL of elderly patients } \\
\text { with motor disorders. }\end{array}$ & $\begin{array}{l}\text { Getting up from the ground; sit } \\
\text { down and get up from the chair } \\
\text { and move around the house } \\
\text { (SGCT); } 800 \mathrm{~m} \text { walk / run. }\end{array}$ & 10 \\
\hline $\begin{array}{l}\text { Batista, Vilar, Ferreira, } \\
\text { Rebelatto. } 2009 \text { (18) }\end{array}$ & 12 & $\begin{array}{l}\text { To evaluate the active stretching program } \\
\text { on the knee flexors in relation to flexibility, } \\
\text { torque, and functional mobility of elderly. }\end{array}$ & TUG & 16 \\
\hline $\begin{array}{l}\text { Cipriani, Meurer, } \\
\text { Benedetti, Lopres. } 2010 \\
\text { (19) }\end{array}$ & 225 & $\begin{array}{l}\text { To analyze changes of the General } \\
\text { Functional Fitness Index (GFFI) in } 10 \\
\text { months elderly. }\end{array}$ & $\begin{array}{l}\text { General Functional Fitness Index } \\
\text { (GFFI). }\end{array}$ & 14 \\
\hline $\begin{array}{l}\text { Lustosa, Oliveira, } \\
\text { Santos, Guedes, } \\
\text { Parentoni, Pereira. } 2010 \\
\text { (20) }\end{array}$ & 7 & $\begin{array}{l}\text { To check the effect of functional exercise } \\
\text { in community elderly for } 8 \text { weeks, the } \\
\text { impact on DLIA and unipodalic balance. }\end{array}$ & $\begin{array}{l}\text { Lawton and Brody scale; } \\
\text { Unipodal support LLL / RLL. }\end{array}$ & 14 \\
\hline $\begin{array}{l}\text { Lustosa, Silva, Coelho, } \\
\text { Pereira, Parentoni, } \\
\text { Pereira. } 2011 \text { (21) }\end{array}$ & 32 & $\begin{array}{l}\text { To check the effect of load muscle strength } \\
\text { training in functional capacity and muscle } \\
\text { strength of the knee extensors and their } \\
\text { association, post-workout, on pre-frail } \\
\text { elderly community. }\end{array}$ & TUG; 10 meters walking test. & 21 \\
\hline $\begin{array}{l}\text { Moraes, Correa, Pinto, } \\
\text { Schuch, Radaelli, Gaya, } \\
\text { et al. } 2012 \text { (22) }\end{array}$ & 45 & $\begin{array}{l}\text { To check the effects on life quality of } \\
\text { elderly, strength programs in functional } \\
\text { capacity, reaction time and maximum } \\
\text { strength. }\end{array}$ & $\begin{array}{l}\text { Sitting down and standing up } \\
\text { from the chair test }(30 \mathrm{sec}) \text {. }\end{array}$ & 20 \\
\hline $\begin{array}{l}\text { de Moraes, Souza, } \\
\text { Pinheiro, Irigoyen, } \\
\text { Medeiros, Koike. } 2011 \\
\text { (23) }\end{array}$ & 36 & $\begin{array}{l}\text { To investigate the effects of a multi- } \\
\text { components program of physical fitness } \\
\text { and functional capacity of hypertensive } \\
\text { elderly patients. }\end{array}$ & $\begin{array}{l}\text { Sit down and stand up from } \\
\text { the chair and move around the } \\
\text { house (SSCT); Putting socks on } \\
\text { test. (PST). }\end{array}$ & 17 \\
\hline $\begin{array}{l}\text { Locks, Costa, Koppe, } \\
\text { Yamaguti, Garcia, } \\
\text { Gomes. } 2012 \text { (24) }\end{array}$ & 45 & $\begin{array}{l}\text { To evaluate the stretching and / or resisted } \\
\text { exercise effetct, followed by detraining, on } \\
\text { the functional status of the elderly. }\end{array}$ & $\begin{array}{l}6 \text { min. walking test; Sitting } \\
\text { down and standing up from the } \\
\text { chair test (5 times). }\end{array}$ & 19 \\
\hline $\begin{array}{l}\text { Bento, Pereira, } \\
\text { Ugrinowitsch, Rodacki. } \\
2012 \text { (25) }\end{array}$ & 37 & $\begin{array}{l}\text { To analyze the effects of an aquatic } \\
\text { exercise program in torque peak and } \\
\text { its development rate during isometric } \\
\text { contractions in the lower limbs and the } \\
\text { performance of functional tests in the } \\
\text { elderly. }\end{array}$ & $\begin{array}{l}\text { Sitting down and standing up } \\
\text { from the chair test ( } 30 \mathrm{sec}) ; \text { Sit } \\
\text { and reach; } 6 \text { min walk; } 8 \text { Foot } \\
\text { Up And Go. }\end{array}$ & 17 \\
\hline $\begin{array}{l}\text { Simão, Avelar, Gomes, } \\
\text { Neves, Mendonça, } \\
\text { Miranda, et al. } 2012 \\
\text { (26) }\end{array}$ & 32 & $\begin{array}{l}\text { To investigate the effects of squat } \\
\text { exercises with whole body vibration on } \\
\text { plasma concentration of inflammatory } \\
\text { markers and functional performance in } \\
\text { elderly with osteoarthritis }(\mathrm{OA}) \text { of the knee. }\end{array}$ & $\begin{array}{l}6 \text { minutes walking test; Berg } \\
\text { balance scale; } 10 \mathrm{~m} \text { walking } \\
\text { test. }\end{array}$ & 20 \\
\hline $\begin{array}{l}\text { Aguiar, Januario, } \\
\text { Junior, Gerage, Pina, } \\
\text { do Nascimento, et al. } \\
2013 \text { (27) }\end{array}$ & 18 & $\begin{array}{l}\text { To examine the effects of long-term } \\
\text { creatine supplementation combined with } \\
\text { strenght-resisted training, motor functional } \\
\text { performance and body composition of } \\
\text { elderly. }\end{array}$ & $\begin{array}{l}\text { Sitting down and standing up } \\
\text { from the chair test ( } 30 \mathrm{sec}) \text {; } \\
\text { Arm Curl Test; standing up of } \\
\text { the lying position from the floor. }\end{array}$ & 18 \\
\hline
\end{tabular}




\begin{tabular}{|c|c|c|c|c|}
\hline Author / Year & $\begin{array}{c}\text { Total sample } \\
\text { number * }\end{array}$ & Aim & $\begin{array}{l}\text { Instrument } \\
\text { Functioning }\end{array}$ & $\begin{array}{l}\text { Quality } \\
\text { Score ** }\end{array}$ \\
\hline $\begin{array}{l}\text { Raso e Greve. } 2012 \\
\text { (28) }\end{array}$ & 41 & $\begin{array}{l}\text { To determine the effect of an exercise } \\
\text { protocol with weights or aerobic in the } \\
\text { performance of ADLs in elder. }\end{array}$ & $\begin{array}{l}\text { Speed to get up from a sitting } \\
\text { position (SGUSP); Speed to } \\
\text { get up from a lying position } \\
\text { (SGULP); Speed to climb stairs } \\
\text { (SCS); Speed to put on and tie } \\
\text { the sneakers (SPOTS). }\end{array}$ & 16 \\
\hline $\begin{array}{l}\text { Lustosa, Pereira, } \\
\text { Coelho, Pereira, Silva, } \\
\text { Parentoni, et al. } 2013 \\
\text { (29) }\end{array}$ & 32 & $\begin{array}{l}\text { To examine the impact of muscle } \\
\text { resistance on the muscular and functional } \\
\text { performance and interleukin } 6 \text { in pre-frail } \\
\text { women in the community. }\end{array}$ & TUG; 10 m walking test. & 22 \\
\hline $\begin{array}{l}\text { de Andrade, Gobbi, } \\
\text { Coelho,Christofoletti, } \\
\text { Costa, Stella. } 2013 \text { (30) }\end{array}$ & 30 & $\begin{array}{l}\text { To check the effects of an exercise } \\
\text { program on the front cognitive function, } \\
\text { postural control, functional capacity in } \\
\text { Alzheimer's patients. }\end{array}$ & $\begin{array}{l}\text { TUG; Sitting and getting up from } \\
\text { the chair test ( } 30 \mathrm{sec}) \text {, Sit and } \\
\text { reach; Berg balance scale. }\end{array}$ & 21 \\
\hline $\begin{array}{l}\text { Farinatti, Geraldes, } \\
\text { Bottaro, Lima, } \\
\text { Albuquerque, Fleck, et } \\
\text { al. } 2013 \text { (31) }\end{array}$ & 41 & $\begin{array}{l}\text { To investigate the effect of different } \\
\text { frequencies of resistance training on } \\
\text { strength and functional performance in } \\
\text { active elderly women. }\end{array}$ & $\begin{array}{l}\text { TUG; Sitting down and standing } \\
\text { up from the chair test ( } 5 \text { times); } \\
\text { Pace speed tests. }\end{array}$ & 20 \\
\hline $\begin{array}{l}\text { Pinto, Correa, Radaelli, } \\
\text { Cadore, Brown, Bottaro. } \\
2013 \text { (32) }\end{array}$ & 36 & $\begin{array}{l}\text { To evaluate the short-term effects of } \\
\text { strength training program on muscle } \\
\text { quality and functional capacity of elderly } \\
\text { women. }\end{array}$ & $\begin{array}{l}\text { Sitting down and standing up } \\
\text { from the chair test ( } 30 \mathrm{sec}) ; 8 \\
\text { Foot Up And Go. }\end{array}$ & 19 \\
\hline $\begin{array}{l}\text { Barduzzi, Junior, Neto, } \\
\text { Aveiro. } 2013 \text { (33) }\end{array}$ & 15 & $\begin{array}{l}\text { To evaluate the impact of aquatic physical } \\
\text { therapy and terrestrial in the functional } \\
\text { capacity of elderly patients with } 0 \mathrm{~A} \text {. }\end{array}$ & $\begin{array}{l}\text { General pace speed; Rapid } \\
\text { pace test ( } 25 \mathrm{~m}) \text {; Up and down } \\
\text { stairs. }\end{array}$ & 18 \\
\hline $\begin{array}{l}\text { de Araujo, de Oliveira, } \\
\text { Martins, Pereira, } \\
\text { Copetti, Safons et al. } \\
2013 \text { (34) }\end{array}$ & 28 & $\begin{array}{l}\text { To evaluate the chronic effects of } \\
\text { equotherapy on functional mobility, muscle } \\
\text { strength and balance in the elderly. }\end{array}$ & $\begin{array}{l}\text { TUG; Sitting down and standing } \\
\text { up from the chair test }(30 \mathrm{sec}) \text {; } \\
\text { Berg balance scale. }\end{array}$ & 18 \\
\hline $\begin{array}{l}\text { Arcoverde, Deslandes, } \\
\text { Moraes, Almeida, } \\
\text { de Araujo, Vasques, } \\
\text { Silveira, et al. } 2014 \text { (35) }\end{array}$ & 20 & $\begin{array}{l}\text { To evaluate the effect of aerobic exercise } \\
\text { on cognition and functional capacity in } \\
\text { patients with Alzheimer's. }\end{array}$ & $\begin{array}{l}\text { Berg balance scale; TUG; Sitting } \\
\text { down and standing up from the } \\
\text { chair test ( } 30 \mathrm{sec}) \text {. }\end{array}$ & 20 \\
\hline $\begin{array}{l}\text { Abrahin, Rodrigues, } \\
\text { Nascimento, Grigoletto, } \\
\text { Sousa, Marçal. } 2014 \\
\text { (36) }\end{array}$ & 19 & $\begin{array}{l}\text { To compare the effects of resistance } \\
\text { training on the inspiratory and expiratory } \\
\text { pressure, functional performance and } \\
\text { muscle strength in elderly women. }\end{array}$ & $\begin{array}{l}\text { Sitting down and standing up } \\
\text { from the chair test ( } 30 \mathrm{sec}) \text {. }\end{array}$ & 17 \\
\hline $\begin{array}{l}\text { da Silva e Berbel } 2015 \\
\text { (37) }\end{array}$ & 19 & $\begin{array}{l}\text { Evaluate the benefit of senior dance related } \\
\text { to the balance and } A D L \text { in the elderly. }\end{array}$ & Lawton e Brody scale. & 11 \\
\hline
\end{tabular}

Note: * Elderly composed sample; ** Maximum score according to 27 questions of the Downs and Black Scale; min: minutes; sec: seconds; m: meter; RLL: right lower limb; LLL: left lower limb; ADL: activities of daily living.

Twenty-five instruments, selected, (tests, indexes and scales) were used to measure the functioning of the elder for encoding the domains of ICF, listed in Table 2. The analysis in the frequency of instruments such as the Sitting down and standing up from the chair test, the TUG (Timed up and go test) and the 6 minutes walking test, showed in articles more frequently than others, twelve, nine, and six articles, respectively, as shown in Table 2. 
Table 2 - Frequency distribution of the instruments included and of the domains of the International Classification of Functioning and Health (ICF) contained in each instrument

\begin{tabular}{|c|c|c|}
\hline Instrument Functioning & Frequency - $\mathrm{n}(\%)$ & Domains ICF: $\mathrm{n}(\%)$ \\
\hline Sitting down and standing up from the chair test $(30 \mathrm{sec})$ & $9(13.84 \%)$ & $\begin{array}{l}\text { Activity: } 3(75 \%) \\
\text { Function and body structure: } 1(25 \%)\end{array}$ \\
\hline TUG - Timed Up And Go Test & $9(13.84 \%)$ & Activity: 6 (100\%) \\
\hline 6 minutes wanlking test & $6(9.2 \%)$ & Activity: 3 (100\%) \\
\hline Berg balance scale & $5(7.7 \%)$ & $\begin{array}{l}\text { Activity: } 112(75.1 \%) \\
\text { Function and body structure: } 2(1.3 \%) \\
\text { Environmental factor: } 35(23.6 \%)\end{array}$ \\
\hline 10 meters wanlking test & $4(6.1 \%)$ & Activity: 2 (100\%) \\
\hline SGLP - Speed to get up from a lying position & $3(4.6 \%)$ & Activity: 2 (100\%) \\
\hline Sitting down and standing up from the chair test (5 times) & $3(4.6 \%)$ & Activity: 5 (100\%) \\
\hline 8 Foot Up And Go & $3(4.6 \%)$ & Activity: $5(100 \%)$ \\
\hline SCS - Speed to climb stairs & $2(3.1 \%)$ & $\begin{array}{l}\text { Activity: } 5 \text { (71.4\%) } \\
\text { Environmental factor: } 2 \text { (28.6\%) }\end{array}$ \\
\hline Arm Curl Test & $2(3.1 \%)$ & Activity: 5 (100\%) \\
\hline Lawton e Brody scale & $2(3.1 \%)$ & $\begin{array}{l}\text { Activity: } 38(69.09 \%) \\
\text { Function and body structure: } 2(3.64 \%) \\
\text { Environmental factor : } 2(3.64 \%) \\
\text { Participation: } 12(21.82 \%) \\
\text { Health condition: } 1(1.82 \%)\end{array}$ \\
\hline Sit and reach & $2(3.1 \%)$ & Activity: 3 (100\%) \\
\hline $\begin{array}{l}\text { GUCMAH - Get up from the chair and move around the house } \\
\text { test }\end{array}$ & $2(3.1 \%)$ & $\begin{array}{l}\text { Activity: } 7 \text { (87.5\%) } \\
\text { Environmental factor: } 1 \text { (12.5\%) }\end{array}$ \\
\hline LLL/RLL Unipodal support & $1(1.54 \%)$ & Activity: 14 (100\%) \\
\hline 800 m. walk/run & $1(1.54 \%)$ & Activity: 4 (100\%) \\
\hline Pace speed test & $1(1.54 \%)$ & Activity: 2 (100\%) \\
\hline GFFI - General functional fitness index & $1(1.54 \%)$ & Activity: $22(100 \%)$ \\
\hline $\mathrm{HAQ}$ questionaire & $1(1.54 \%)$ & Activity: 33 (100\%) \\
\hline Lower Limb Functional Test & $1(1.54 \%)$ & $\begin{array}{l}\text { Activity: } 3(75 \%) \\
\text { Function and body structure: } 1(25 \%)\end{array}$ \\
\hline UKP - Up from the kneeling position & $1(1.54 \%)$ & Activity: 3 (100\%) \\
\hline Obstacle Course Test (OCQTS and OCQLS) & $1(1.54 \%)$ & $\begin{array}{l}\text { Activity: } 6(66.7 \%) \\
\text { Environmental factor: } 3(33.3 \%)\end{array}$ \\
\hline PST - Putting socks on test & $1(1.54 \%)$ & Activity: 2 (100\%) \\
\hline Rapid walking test (25 m) & $1(1.54 \%)$ & Activity: 3 (100\%) \\
\hline SPOTS - Speed to put on and tie the sneakers & $1(1.54 \%)$ & Activity: 2 (100\%) \\
\hline General pace speed & $1(1.54 \%)$ & Activity: 4 (100\%) \\
\hline SGUSP - Speed to get up from sitting position & $1(1.54 \%)$ & Activity: 2 (100\%) \\
\hline
\end{tabular}

Note: s.: seconds; RLL: right lower limb; LLL: left lower limb; min.: minutes; m.: meters. 
The collected instruments were coded according to the ICF domains and the results were expressed in the form of table and graph (Table 2 and Figure 2 ). The frequency in which the ICF domains appear in the collected instruments were: health condition
$(0.28 \%)$, function and body structure $(1.68 \%)$, activity $(82.68 \%)$, share (3.35\%), environmental factors (12.01\%) and people factors (0\%). Regarding the field of personal factors there was no incidence/approach in any of the instruments.

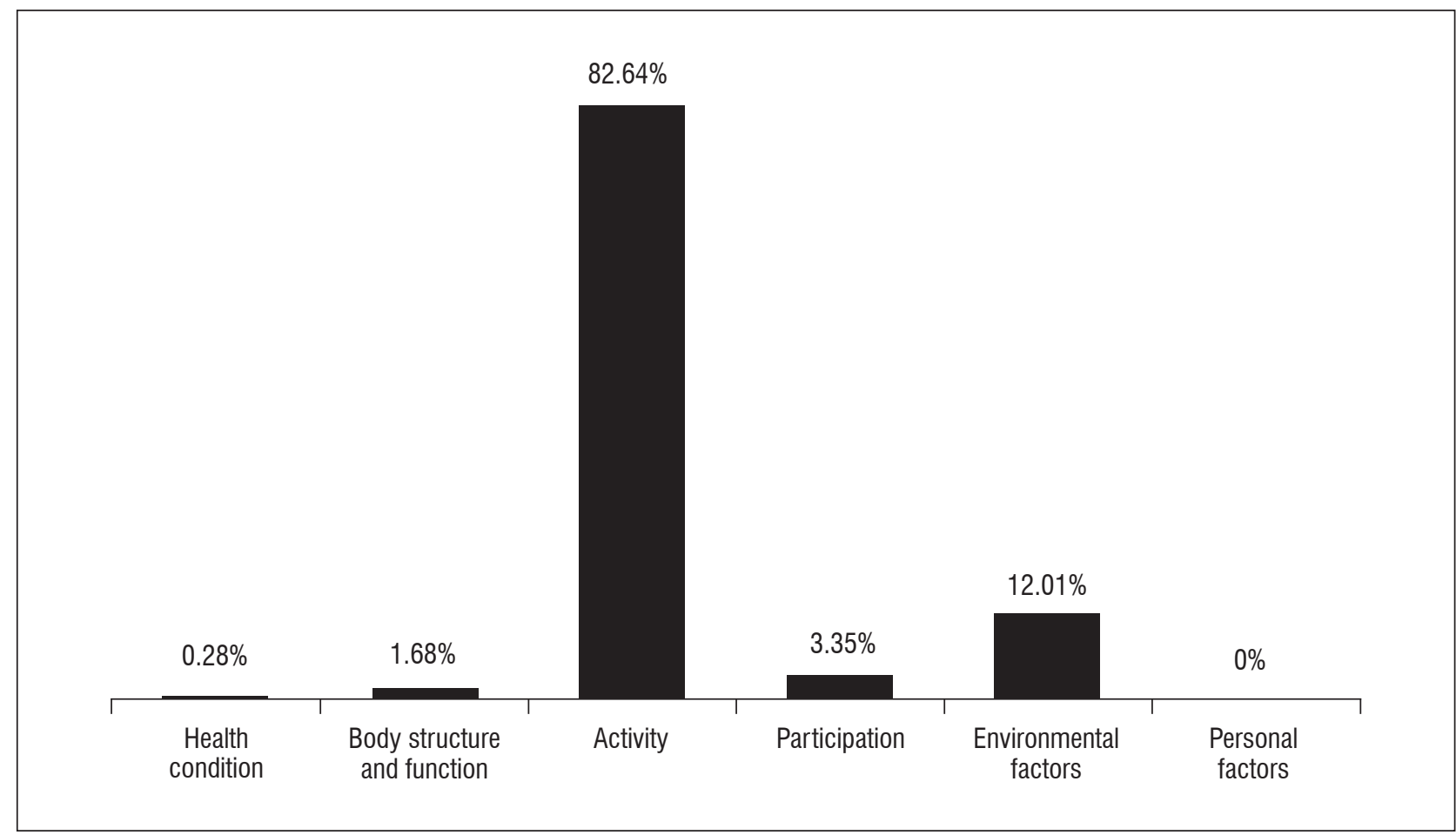

Figure 2 - ICF encoding total frequency in the included instruments.

\section{Discussion}

By the results of this article it is clear that the scientific literature regarding the functioning in the elderly is relatively abundant considering that great amount of publications in this article were found. However, as the final sample, remained 29 articles, containing 26 instruments. The amples of this research, which were subject of this article, ranged from 7 (20) to 225 (19) subjects, wherein most publications had 20 to 30 subjects. These results suggest that studies on elderly functioning with more robust samples should be encouraged, as in other countries, where studies with extended samples (38-40) or populational (41-43) are performed.

The displayed results have shown an increasing trend in the volume of publications in the studied period. Among the studied articles, six were published in 2013 and five in 2012; three articles were published in 2008; two in 2007, 2009, 2010, 2011, 2014; one publication in 2004 and 2015; and 2005 and 2006 did not record any publication. The objectives of the selected publications for this article are fundamentally related to the verification of the effect of any intervention in the studied group, which shows itself consistent with the purpose of this review, if studied only scientific materials related to intervention studies. As regards the assessment of the syudied publications quality, there was a variation of 10 (17) to 22 points (29). This fact shows that the published and studied material have good quality, reflecting the methodological severity in the research execution.

Among the instruments used in the articles selected for this study, the sitting down and standing up from the chair test (30 seconds) was one of the most frequent, being used by 9 articles. This test was planned to be used, together, in the form of a battery of tests proposed for the study of physical parameters with functional mobility among independent elderly (44). This fact shows that the test has been used individually and dissociated form the rest of the test battery to which it belongs, addressing therefore 
the functioning in a reductionist way. Moreover, in the creating process of the test battery to which the sitting down and standing up test (30 seconds) belongs, the functioning was addressed through the adaptation of an ICF previous explanatory model. The model used in the creation of this test battery includes disability as a result of a linear process that starts by diseases related factors, lifestyle and physical inactivity (44). If there are any changes in these components, the process would produce functional changes and would end in the occurrence of disability. The understanding of the functioning as a linear process should not be encouraged, considering that there are already more complete models, being the ICF the most current and recomended expression (45). Through argumentation developed here, you realize that the most commonly used instrument in studies of functioning in the elderly is being used disassociated from the other tests in the belonging batery. Besides, the referred battery is based on an explanatory model, that should have its discontinued use because there is a more complete and modern model.

Another test used with the same frequency as the previous was the TUG test, being used for falling risk tracking (46) and functional mobility admeasurement (47) plus, this test was created for the last mentioned goal (48). It should be noted that mobility is only one of the dimensions or areas of functioning. The World Health Organization Disability Assessment Schedule (WHODAS), for example, which is an instrument recommended by the WHO, the mobility is one of the 6 areas covered by the instrument (49). It can be seen by the above discussion, that when using the TUG as functional assessment tool, there is a distortion and functioning phenomenon is understood only as related to mobility, leaving aside issues such as life activities, interpersonal relationships, self-care, cognition participation, besides the environmental factors, body structures and functions, as recommended by the ICF (4). The 6-minute walking test was used in 6 researches. Note that this test suffers the same bias that the TUG because it would gauge mobility (50), ignoring other functioning aspects, as told previously.

The Berg balance scale was used in 5 articles and is used to evaluate the risk of falls (51), but it was originally designed for balance evaluation (52). The ICF defines balance as a body's function component, belonging to Chapter 2 "Sensory functions and pain", specifically cited by b235 code, "Vestibular function", which includes the "Sensory functions of the inner ear related to position, balance and movement" (4). Therefore, using the Berg balance scale as functioning indicator means an extreme simplification. By taking balance as functioning indicator, there is the functioning underestimation and devaluation by neglecting other ICF proposed aspects.

Some other instruments used to measure functioning as VSSPs, VSSP2, VCS and VWS are, in nature flexibility and agility mesurement tests, also representing reductionism when using these elements as functioning indicators. The sit and reach test also faces the same problem because it was designed to measure flexibility (53). The Lawton and Brody scale was designed to evaluate the instrumental activities of daily living (54). Like other instruments, can not be taken for functioning measurement because it works only with one phenomenon belonging aspect. Other tests showed a lower use frequency as the single leg support test, which was designed to measure risk of falls (55); the obstacle course test works the pace adaptability (56); the lower limb functional test evaluates balance and speed (11); the stand up from kneeling position and get up and sit in the chair 5 times tests reproduce situations where the decubitus change and agility are tested; walking or running 800 meters, walking and walking speed test work mobility and gait; test putting on socks, an activity of daily living; 8 feet up and go test was designed to assess the dynamic balance (57); the general functional fitness index addresses the coordination, upper limbs strength endurance, aerobic endurance, flexibility, dynamic agility or balance (58); the arm curl test was designed to evaluate the upper limb strength (59); and the get up from the chair and move around the house test works with daily living activities (60). All tests referred to in this paragraph incur on the inconsistency of taking the functioning the reduced way, using one or some of its aspects as an indicator.

The Health assessment questionnaire (HAQ) is a proposed tool to gauge functional capacity, consisting of 8 areas (dressing, getting up, eating, walking, personal hygiene, reach objects, grasp objects and other activities). Also this instrument clearly ignores some components of the functional model proposed by the ICF.

It is clearly observed that none of the instruments used to collect information about functioning does not respect the model presented by the ICF. The same 
bias is found in almost all instruments: functioning is understood or measured only by one or some of its components, addressed in a reductive and simplified way.

All researched instruments in this article include items related to the activities domain. Lawton and Brody scale is the one contemplating larger amount of ICF domains, excluding only the contextual factors. Besides activities, the Berg salance scale includes functions and body structures and environmental factors; the get up from the chair and move around the house test; the obstacle course test; and the climbing stairs speed test contemplate environmental factors; the sit down and get up of the chair test (30 seconds) and the lower limb functional test contemplate the function and body structure. All the other tests (19 instruments) only include the activity field. Imbalance can clearly be seen between functioning domains evaluated by the studied instruments, with a strong predominance of activities domain, which is evidenced by Figure 2, in which the activities are the area most often found in the analyzed instruments.

Note that the option for intervention research study may lead the reader to reason that the result would be expected because this type of study can essentialy treat functions and body structures. However, the results of this study themselves contradict this argument because they show that the activities were more frequent in the analyzed articles. In addition, central role should not be assigned to study design but to the functioning in its outcome. Regardless of the study design, the functioning concept should not vary.

Considering that this study shows disagreement between the functioning approach and the model proposed by the ICF, a newly translated and adapted instrument for use in Brazil may be of special interest. It is the WHODAS, as described before, respects the model proposed by the ICF. Furthermore, because it is composed of 36 questions at most, has relatively reduced application time and generates scores for domains, allowing individual analysis of these domains and the targeted interventions planning (49). Certainly this instrument is also open to criticism and the main one is the fact of not having a specific domain for environmental factors. However, even with this weakness, it is shown as a good alternative to the functioning assessment.

\section{Conclusion}

Overall, the results of this review indicate gaps in the subject that must be corrected. The main problem is the functioning interpretation predominantly in the activities field, with few studies and tools that address other areas equally. Instruments that include participation and environmental factors area in the evaluation of functioning should be proposed or used for a correct functioning mesurement in all conceptual extension of it, as proposed by the ICF.

\section{References}

1. Brasil. Conselho Nacional de Secretários de Saúde. Vigilância em Saúde/ Conselho Nacional de Secretários de Saúde. Brasília: CONASS; 2007. Portuguese.

2. Barbosa BR, Almeida JM, Barbosa MR, Barbosa LARR. Avaliação da capacidade funcional de idosos e fatores associados á incapacidade. Cienc Saude Colet. 2014;19(8):3317-25.

3. Carvalho GS. Avaliação fisioterapêutica da funcionalidade do idoso com bases no índice Katz e escala MIF [undergraduate thesis]. Rio de Janeiro: Universidade Veiga de Almeida; 2008. Portuguese.

4. Centro Colaborador da Organização Mundial da Saúde para a Família de Classificações Internacionais, organizador. CIF: Classificação Internacional de Funcionalidade, Incapacidade e Saúde. São Paulo: Editora da Universidade de São Paulo; 2003. Portuguese.

5. Sampaio RF, Luz MT. Funcionalidade e incapacidade humana: explorando o escopo da classificação internacional da Organização Mundial da Saúde. Cad Saude Publica. 2009;25(3):475-83.

6. Downs SH, Black N. The feasibility of creating a checklist for the assessment of the methodological quality both of randomised and non-randomised studies of health care interventions. J Epidemiol Community Health. 1998;52(6):377-84.

7. Simic M, Hinman RS, Wrigley TV, Bennell KL, Hunt MA. Gait modification strategies for altering medial knee joint load: a systematic review. Arthritis Care Res (Hoboken). 2011;63(3):405-26. 
8. Deeks JJ, Dinnes J, D’Amico R, Sowden AJ, Sakarovitch $\mathrm{C}$, Song F, et al. Evaluating non-randomised intervention studies. Health Tecnol Assess. 2003;7(27):iii-x, 1-173.

9. Cieza A, Geyh S, Chatterji S, Kostanjsek N, Ustun B, Stucki G. ICF linking rules: an update based on lessons learned. J Rehabil Med. 2005;37(4):212-8.

10. Zamboni AB, Thommazo AD, Hernandes ECM, Fabbri SCPF. (2010) StArt Uma Ferramenta Computacional de Apoio à Revisão Sistemática. In: Brazilian Conference on Software: Theory and Practice - Tools session. UFBA.

11. Bastone AC, Jacob Filho W. Effect of an exercise program on functional performance of institutionalized elderly. J Rehabil Res Dev. 2004;41(5):659-68.

12. Montenegro SMRS, Silva CAB. Os efeitos de um programa de fisioterapia como promotor de saúde na capacidade funcional de mulheres idosas institucionalizadas. Rev Bras Geriatr Gerontol. 2007;10(2):161-78

13. Bottaro M, Machado SN, Nogueira W, Scales R, Veloso $\mathrm{J}$. Effect of high versus low-velocity resistence training on muscular fitness and functional performance in older man. Eur J Appl Physiol. 2007;99(3):257-64.

14. Barbosa JMM, Prates BSS, Gonçalves CF, Aquino AR, Parentoni AN. Efeito da realização simultânea de tarefas cognitivas e motoras no desempenho funcional de idosos da comunidade. Fisioter Pesqui. 2008;15(4):374-9.

15. Geraldes AAR, Carvalho J, Dias Jr NM, Farinatti PTV, Albuquerque RB. Efeitos de um programa de treinamento resistido com volume e intensidade moderados $\mathrm{e}$ velocidade elevada sobre o desempenho funcional de mulheres idosas. R Bras Ci e Mov. 2007;15(3):53-60.

16. Carvalho AR, Assini TCKA. Aprimoramento da capacidade funcional de idosos submetidos a uma intervenção por isostretching. Rev Bras Fisioter. 2008;12(4):268-73.

17. Perez AJ, Zimperer C, Silva RS. Efeitos de um programa de exercícios aquáticos na atividade de vida diária de idosos portadores de transtornos motores. Rev Bras Cienc Mov. 2009;17(2):1-22.

18. Batista LH, Vilar AC, Ferreira JJA, Rebelatto JR, Salvini TF. Active stretching improves flexibility, joint torque, and functional mobility in older women. Am J Phys Med Rehabil. 2009;88(10):815-22.
19. Cipriani NCS, Meurer TS, Benedetti TRB, Lopres MA. Aptidão funcional de idosas praticantes de atividades físicas. Rev Bras Cineantropom Desempenho Hum. 2010;12(2):106-11.

20. Lustosa LP, Oliveira LA, Santos LS, Guedes RC, Parentoni NA, Pereira LSM. Efeito de um programa de treinamento funcional no equilíbrio postural de idosas da comunidade. Fisioter Pesqui. 2010;17(2):153-6.

21. Lustosa LP, Silva JP, Coelho FM, Pereira DS, Parentoni NA, Pereira LSM. Efeito de um programa de resistência muscular na capacidade funcional e na força muscular dos extensores do joelho em idosas pré-frageis da comunidade: ensaio clínico aleatorizado do tipo crossover. Rev Bras Fisioter. 2011;15(4):318-24.

22. Moraes K, Correa CS, Pinto RS, Schuch F, Radaelli R, Gaya A, et al. Efeitos de três programas de treinamento de força na qualidade de vida de idosas. Rev Bras Ativ Fis e Saude. 2012;17(3):181-7.

23. Moraes WM, Souza PRM, Pinheiro MHNP, Irigoyen MC, Medeiros A, Koike MK. Exercise training program based on minimum weekly frequencies: effects on blood pressure and physical fitness in elderly hypertensive patients. Rev Bras Fisioter. 2011;16(2):114-21.

24. Locks RR, Costa TC, Koppe S, Yamaguti AM, Garcia MC, Gomes ARS. Effects of strength and flexibility training on functional performance of healthy older people. Rev Bras Fisioter. 2012;16(3):184-90.

25. Bento PCB, Pereira G, Ugrinowitsch C, Rodacki ALF The effects of a water-based exercise program on strength and functioning o folder adults. J Aging Phys Act. 2012;20(4):469-83.

26. Simão AP, Avelar NC, Gomes RT, Neves CD, Mendonça VA, Miranda AS, et al. Functional Performance and Inflammatory Cytokines after squat exercises and whole-body vibration in elderly individuals with knee osteoarthritis. Arch Phys Med Rehabil. 2012;93(10):1692-700.

27. Aguiar AF, Januario RS, Pires Jr R, Gerage AM, Pina FL, Nascimento MA, et al. Long-term creatine supplementation improves muscular performance during resistence training in older woman. Eur J Appl Physiol. 2013;113(4):987-96.

28. Raso V, Greve JMA. Exercício aeróbico ou com pesos melhora o desempenho nas atividades da vida diária de mulheres idosas. Rev Bras Med Esporte. 2012;18(2):87-90. 
29. Lustosa LP, Pereira LSM, Coelho FM, Pereira DS, Silva JP, Parentoni AN, et al. Impact of an exercise program on muscular and functional performance and plasma levels of interleukin 6 and soluble receptor tumor necrosis factor in prefrail community-dwelling older woman: a randomized controlled trial. Arch Phys Med Rehabil. 2013;94(4):660-6.

30. Andrade LP, Gobbi LT, Coelho FG, Christofoletti G, Costa JL, Stella F. Benefits of multimodal exercise intervention for postural control and frontal cognitive functions in individuals with Alzheimer's disease: a controlled trial. J Am Geriatr Soc. 2013;61(11):1919-26.

31. Farinatti PT, Geraldes AA, Bottaro MF, Lima MV, Albuquerque RB, Fleck SJ. Effects of different resistance training frequencies on the muscle strength and functional performance of active women older than 60 years. J Strength Cond Res. 2013;27(8):2225-34.

32. Pinto RS, Correa CS, Radaelli R, Cadore EL, Brown LE, Bottaro M. Shot-term strenght training improves muscle quality and functional capacity of elderly women. Age (Dordr). 2013;36(1):365-72.

33. Barduzzi GO, Rocha Jr PR, Souza Neto JS, Aveiro MC. Capacidade funcional de idosos com osteoartrite submetidos a fisioterapia aquática e terrestre. Fisioter Mov. 2013;26(2):349-60.

34. Araujo TB, Oliveira RJ, Martins WR, Pereira MM, Copetti F, Safons MP. Effects of hippotherapy on mobility, strength and balance in elderly. Arch Gerontol Geriatr. 2013;56(3):478-81.

35. Arcoverde C, Deslandes A, Moraes H, Almeida C, Araujo NB, Vasques PE, et al. Treadmill training as na augmentation treatment for Alzheimer's disease: a pilot randomized controlled study. Arq Neuropsiquiatr. 2014;72(3):190-6.

36. Abrahin O, Rodrigues RP, Nascimento VC, Grigoletto MES, Sousa EC, Marçal AC. Single and multiple set resistence training improves skeletal and respiratory muscle strength in elderly women. Clin Interv Aging. 2014;9:1775-82.

37. Silva AFG, Berbel AM. O benefício da dança sênior em relação ao equilíbro e ás atividades de vida diárias no idoso. ABCS Health Sci. 2015;40(1):16-21.
38. Chumbler NR, Mann WC, Wu S, Schmid A, Kobb R. The association of home-telehealth use and care coordination with improvement of functional and cognitive functioning in frail elderly men. Telemed J E Health. 2004;10(2):129-37.

39. Karinkanta S, Heinonen A, Sievanen H, Uusi-Rasi K, Fogelholm M, Kannus P. Maintenance of exercise-induced benefits in physical functioning and bone among elderly women. Osteoporos Int. 2009;20(4):665-74.

40. van de Rest $\mathrm{O}$, van der Zwaluw NL, Tieland M, Adam JJ, Hiddink GJ, van Loon LJ, et al. Effect of resistance-type exercise training with or without protein supplementation on cognitive functioning in frail and pre-frail elderly: secondary analysis of a randomized, doubleblind, placebo-controlled trial. Mech Ageing Dev. 2014;136-137:85-93.

41. Moonem JE, Foster-Dingley JC, de Ruijter W, van der Grond J, Bertens AS, van Buchem MA, et al. Effect of Discontinuation of Antihypertensive Treatment in Elderly People on Cognitive Functioning-the DANTE Study Leiden: A Randomized Clinical Trial. JAMA Intern Med. 2015;175(10):1622-30.

42. Rebok GW, Ball K, Guey LT, Jones RN, Kim HY, King JW, et al. Ten-year effects of the advanced cognitive training for independent and vital elderly cognitive training trial on cognition and everyday functioning in older adults. J Am Geriatri Soc. 2014;62(1):16-24.

43. Okochi J, Takahashi T, Takamuku K, Escorpizo R. Staging of mobility, transfer and walking functions of elderly persons based on the codes of the International Classification of Functioning, Disability and Health. BCM Geriatr. 2013;13:16

44. Rikli RE, Jones CJ. Devolopment and Validation of a Functional Fitness Test for Community-Residing Older Adults. J Aging Phys Act. 1999;7(2):129-61.

45. Masala C, Petretto DR. From disablement to enablement: conceptual models of disability in the 20th century. Disabil Rehabil. 2008;30(17):1233-44.

46. Barry E, Galvin R, Keogh C, Horgan F, Fahey T. Is the Timed Up and Go test a useful predictor of risk of falls in community dwelling older adults: a systematic review and meta-analysis. BMC Geriatrics. 2014;14:14.

47. Al Haddad MA, John M, Hussain S, Bolton CE. Role of the Timed Up and Go Test in Patients With Chronic Obstructive Pulmonary Disease. J Cardiopulm Rehabil Prev. 2016;36(1):49-55. 
48. Podsiadlo D, Richardson S. The timed "Up \& Go": a test of basic functional mobility for frail elderly persons. J Am Geriatr Soc. 1991;39(2):142-8.

49. Organização Mundial da Saúde. Avaliação de Saúde e Deficiência: manual do WHO disability assessment schedule (WHODAS 2.0). Tradução e revisão: Castro SS, Leite CF. Uberaba (Brazil): Universidade Federal do Triângulo Mineiro; 2015. Portuguese.

50. Harada ND, Chiu V, Stewart AL. Mobility related function in older adults: assessment with a 6-minute walk test. Arch Phys Med Rehabil. 1999;80(7):837-41.

51. Pereira VV, Maia RA, Silva SM. The functional assessment Berg Balance Scale is better capable of estimating fall risk in the elderly than the posturographic Balance Stability System. Arq Neuro-Psiquiatr. 2013;71(1):5-10.

52. Berg KO, Wood-Dauphinee SL, Williams JI, Maki B. Measuring balance in the elderly: validation of an instrument. Can J Public Health. 1992;83(Suppl 2):S7-11.

53. Wells KF, Dillon EK. The sit and reach: a test of back and leg flexibility. Res Q Exerc Sport. 1952;23:115-8.

54. Lawton MP, Brody EM. Assessment of older people: self-maintaining and instrumental activities of daily living. Gerentologist. 1969;9(3):179-86.
55. Vellas BJ, Wayne SJ, Romero L, Baumgartner RN, Rubenstein LZ, Garry PJ. One-leg balance is an important predictor of injurious falls in older persons. J Am Geriatr Soc. 1997;45(6):735-8.

56. Balasubramanian CK, Clark DJ, Fox EJ. Walking Adaptability after a Stroke and Its Assessment in Clinical Settings. Stroke Res Treat. 2014;2014:591013.

57. Rikli RE, Jones CJ. Measuring functional fitness of older adults. J Active Aging. 2002 Mar-Apr;24-30.

58. Antes DL, Rossato LC, Souza AG , Benedetti TRB, Borges GF, Mazo GZ. Índice de aptidão funcional geral e sintomas depressivos em idosos. Rev Bras Cineantropom Desempenho Hum. 2012;14(2):125-33.

59. Seemann T, Schmitt CW, Guimarães ACA, Korn S, Simas JPN, Souza MC, et al. Trainability and reversibility in physical fitness among elderly persons taking part in an intervention program. Rev Bras Geriatr Gerontol. 2016;19(1):129-37.

60. Andreotti RA, Okuma SS. Validação de uma bateria de testes de atividades da vida diária para idosos fisicamente independentes. Rev Paul Educ Fis. 1999;13(1):46-66.
Received in 07/04/2016 Recebido em 04/07/2016

Approved in 08/02/2016 Aprovado em 02/08/2016 